\title{
INCREASED SENSITIVITY OF DMD LYMPHOBLASTOID CELL TO LOW DOSES OF X-IRRADIATION
}

\author{
L. MELCHIORRI*, S. CARTURAN*, D. FERRARI ${ }^{\dagger}$, F. DI VIRGILIO ${ }^{\dagger}$, O.R. BARICORDI* \\ *Institute of Medical Genetics, University of Ferrara, Italy. \\ ${ }^{\dagger}$ Institute of General Pathology, University of Ferrara, Italy.
}

\begin{abstract}
SUMMARY
Several cell membrane abnormalities affecting various cell populations have been reported in Duchenne muscular dystrophy (DMD) by different investigators. In peripheral blood lymphocytes intrinsic cellular membrane defect evidentiated by impairment of capping capacities has been repeatedly obtained, suggesting that DMD product could act in such cellular phenotype at the cytoskeletal compartment. It has been previously reported that lymphoid cells are characterized by high radiosensitivity. On the assumption that DMD phenotypes could increase this susceptibility, we have compared the radiosensitivity of normal and DMD lymphoblastoid cell lines (LCLs) to small doses ( $0-2 \mathrm{~Gy})$ of $\mathrm{x}$-irradiation. The results obtained suggest an increased sensitivity of DMD cells without $\mathrm{Ca}++$ uptake or apoptotic phenomena, associated with an effect upon cell cycle length.
\end{abstract}

KEY WORDS $\quad \mathrm{X}$-rays Duchenne muscular dystrophy

\section{INTRODUCTION}

Duchenne muscular dystrophy (DMD) is a X-linked disease with an incidence of 1 in 3500 male births. The DMD gene product is a large extended rod shaped protein called dystrophin. Its amino terminal portion is similar in sequence to alfa actinin, while its central portion resembles spectrin, a membrane cytoskeletal component.

The precise role of this DMD gene product is still unknown, however many distinct functions have been suggested related to membrane stability, force transduction and, in non contractile tissue, membrane specialization. By immunochemistry studies, dystrophin has been firstly detected at the plasma membrane of skeletals, cardiac and smooth muscles. A promoter active in such tissues and a neuron specific promoter control the production of two $14 \mathrm{~kb}$ mRNAs, translated into $427 \mathrm{KDa}$ proteins differing in the $\mathrm{N}$-terminal. Furthermore, other alternative transcripts whose mRNA encodes only the gene portion have been identified in other tissues. At least five distinct promoters responsible for independent cell-type specific expression of dystrophin are well documented, suggesting that DMD gene is expressed in many, and possibly all, tissues (Ahn and Kunkel, 1993).

Correspondence to: Olavio R. Baricordi, Institute of Medical Genetics, Via L. Borsari 46, 44100 Ferrara, Italy. Tel: +39532 291382. Fax: +39532247618. 
Several cell membrane abnormalities affecting various cell populations have been reported in DMD by different investigators. In particular, peripheral blood lymphocytes showed impairment of the immunological redistribution (capping) of some membrane determinants as sIgs and PHA receptor firstly detected in B cell population and later on the whole lymphocyte population (HLA molecules) (Sensi $e t$ al., 1984). Further studies suggested that capping impairment is an intrinsic cellular defect and not a secondary phenomenon related to the course of the disease. In fact, lowered capping capacities were shown to be retained by EBV transformed lymphoblastoid cell lines (LCLs) from DMD patients (Baricordi et al., 1989). Moreover, in vitro correction of the abnormality was observed as a consequence of pretreatment with colchicine. The well known influence of colchicine on microtubule polymerization suggested involvement of the cytoskeletal component in the determination of the cellular disfunction.

In the present study we have investigated the radiosensitivity of cells from DMD LCLs. The results obtained show an increased sensitivity to $\mathrm{x}$-irradiation in DMD cells when compared to healthy LCL cells suggesting a difference related to the disease.

\section{MATERIALS AND METHODS}

\section{Cells}

LCLs obtained by EBV transformation (Sudgen and Marks, 1977) from DMD and healthy subjects were grown in Iscove medium (Gibco) supplemented with $10 \%$ fetal calf serum, $2 \mathrm{mM}$ glutamine, $10 \mathrm{U} / \mathrm{ml}$ penicillin. Cells cultures were monitored daily and harvested for experiments when exponential growth was observed.

\section{Irradiation}

Cell suspensions were exposed to $\mathrm{x}$-rays $(0-2.00 \mathrm{~Gy})$ using a $\mathrm{x}$-ray machine, operating at $170 \mathrm{kV}$ and $10 \mathrm{~mA}$ with $4-\mathrm{mm} \mathrm{Al}$ filter. After irradiation cells were washed and resuspended in fresh media.

\section{Proliferation assay}

Proliferation assay was performed in triplicate by seeding $0.05 \times 10^{6}$ cells/well in Falcon 3072 microtiter plate. After 48 hours of incubation at $37^{\circ} \mathrm{C}, 1$ microCi $3 \mathrm{H}-$ thymidine (Amity- spec. act. $2 \mathrm{Ci} / \mathrm{m} \mathrm{mol}$ ) was added to each well overnight. The counts per minute obtained were expressed as mean of triplicate cultures. For the evaluation of the residual proliferative response at different $\mathrm{x}$-ray treatment the cpm of non irradiated cells were considered as maximum proliferation.

Simultaneous bulk cultures were performed for cell viability assessment.

\section{Cytosolic Ca++ evaluation}

Loading with fura-2/AM and measurement of ( $\mathrm{Ca}++)$ were performed as previously described (Di Virgilio et al., 1988). Briefly, cells were loaded with $4 \mu \mathrm{m}$ fura-2/AM and incubated in a thermostat-controlled $\left(37^{\circ} \mathrm{C}\right)$ and magnetically stirred fluorometer cuvette (Perkin-Elmer LS5). (Ca++)i levels were determined with the 340/480 excitation ratio, at an emission wavelength of $500 \mathrm{~nm}$. 


\section{DNA fragmentation}

DNA fragmentation was analyzed as previously described (Murgia et al., 1991).

Briefly, after irradiation 5-10 × $10^{6}$ cells and suitable controls were incubated at $37^{\circ} \mathrm{C}$ in Iscove medium containing 10\% FCS. 48 hours later cells were lysed by adding in sequence $200 \mu \mathrm{l}$ of lysis buffer (2M NaCl, $50 \mathrm{mM}$ Tris-HCl, $100 \mathrm{mM}$ EDTA), $1 \%$ SDS and $250 \mu \mathrm{l}$ proteinase $\mathrm{K}$ (Boehringer Mannheim). DNA extraction was carried out by the salting-out methods as follows: $400 \mu \mathrm{l}$ of $5 \mathrm{M} \mathrm{NaCl}$ were added to the lysates which were shaken vigorously and centrifuged at $800 \mathrm{x}$ g for 15 minutes. The supernatant was collected and $5 \mathrm{ml}$ of absolute ethanol were added. DNA was washed with $70 \%$ ethanol, resuspended in TE (10 mM TRIS-Cl, $0.2 \mathrm{mM} \mathrm{Na-EDTA} \mathrm{pH} \mathrm{7.5)} \mathrm{and} \mathrm{treated} \mathrm{with} \mathrm{RNAse}$ at $37^{\circ} \mathrm{C}$ for $3 \mathrm{~min}$. Finally DNA was run on $1 \%$ agarose gel containing $0.5 \mu \mathrm{g} / \mathrm{ml}$ of ethidium bromide and visualized under UV light.

\section{Statistical evaluation}

Statistical evaluation of the results obtained were performed by using the Student's t test.

\section{RESULTS}

\section{Proliferation assay}

The lymphoproliferative capacity in healthy and DMD cells was investigated for different $x$-ray doses $(0.25,0.5,1.0,2.0 \mathrm{~Gy})$ at different incubation time (24-48 hours).

After 24 hours no statistical differences were observed in the proliferating capacity between healthy and DMD cultures at each dose and among different dose rates. Instead significant impairment of $3 \mathrm{H}$ thymidine uptake were observed in DMD cultures after 48 hours incubation in three out of four $\mathrm{x}$-irradiation dose rates tested. The results obtained in an analysis performed in six healthy and DMD LCLs is reported in Table 1. Figure 1 shows the results of pairwise comparison in three independent experiments. The residual proliferative activities observed in 13 healthy LCLs and 16 DMD LCLs $48 \mathrm{~h}$ after 2 Gy irradiation are reported in Figure 2. Statistical evaluation of the results showed a significant impairment of the DMD LCLs $(\mathrm{p}<0.01)$.

To investigate the presence of a cell cycle length affect we have tested $3 \mathrm{H}$ uptake in irradiated and non-irradiated cells cultured for 24 hours, washed, and resuspended at the same concentration. Overnight incubation showed a reduced $3 \mathrm{H}$ uptake in irradiated cells suggesting an affect on cell cycle length.

Simultaneous evaluation of the culture absolute cell number showed no significant differences between irradiated and non-irradiated cultures.

\section{Cell counting}

No differences in cell viability, evaluated by phase contrast and dye exclusion, was observed in the different populations.

Absolute cell number for each culture assessed within 24 hours after irradiation showed no significant difference between DMD and healthy cells and among the $\mathrm{x}$ dose rates provided.

A reduced number of cells, when compared to non-irradiated cultures, were observed in the DMD population after 48 hours of incubation time. No significant differences were detected between irradiated and non- irradiated healthy cultures. 
Table 1. Impairment of proliferative activity between healthy and DMD LCLs following $\mathrm{x}$ irridiation.

\begin{tabular}{lcccc}
\hline Gy & 0.25 & 0.5 & 1.0 & 2.0 \\
\hline $\begin{array}{l}\text { healthy } \\
\mathrm{n}=6\end{array}$ & a $96.2+12^{*}$ & $95.5+8.8$ & $92.9+9.9$ & b 85.2+8.4 \\
$\begin{array}{l}\text { DMD } \\
\mathrm{n}=6\end{array}$ & c 87.1+11 & $77.5+7$ & $67.6+8.4$ & d 51.4+6.1 \\
$\mathrm{p}$ & n.s. & $<.02$ & $<.01$ & $<.001$ \\
\hline
\end{tabular}

$\mathrm{a} / \mathrm{b}=\mathrm{n} . \mathrm{s}$.

$\mathrm{c} / \mathrm{d}=\mathrm{n} . \mathrm{s}$.

* $48 \mathrm{~h}$ residual proliferative activities

\section{Cytosolic Ca++ concentration}

Evaluation of the cytosolic $\mathrm{Ca}++$ concentrations performed at 6,24 and 48 hours of cultures did not show any increase in irradiated cells when compared to non-irradiated in DMD and healthy subjects.

\section{DNA fragmentation}

Analysis of the DNA obtained from the different cell cultures 48 hours after 2 Gy irradiation did not detect any differential degradation pattern in DMD and healthy subjects (Figure 3).

\section{DISCUSSION}

It is generally accepted that dystrophin performs a number of distinct cytoskeletal functions related to membrane stability and tissue organization.

Several studies in human and in the mdx mouse models have clearly demonstrated intrinsic membrane defects affecting both mechanical tension and ion fluxes across the cellular membrane. Abnormal influx of $\mathrm{Ca}++$ and defective mechanical tension are in fact suggested as single process or combined mechanisms responsible for the necrosis of the muscle fibres.

The role of dystrophin in Ca++ metabolism is suggested by the elevated intracellular Ca++ (Turner et al., 1988), increased Ca++ leak channel activity (Fong et al., 1990), abnormally high stretch inactivated Ca++ channel activity (Franco and Lansman, 1990) and complex changes in Ca++-sensitivity protease activity (Spencer et al., 1992). Similarly elevated protein turnover (Mac Lennan and Edwards, 1990; Turner et al., 1988) and decreased osmotic membrane stability observed in DMD or mdx cells (Menke and Jockusch, 1991) suggest that dystrophin confers muscular fibre membrane stability.

In DMD patients several abnormalities involving non muscle cells have been described, and in particular the impairment of the capping capacities in peripheral blood lymphocytes has been repeatedly confirmed. Recently different investigators have 


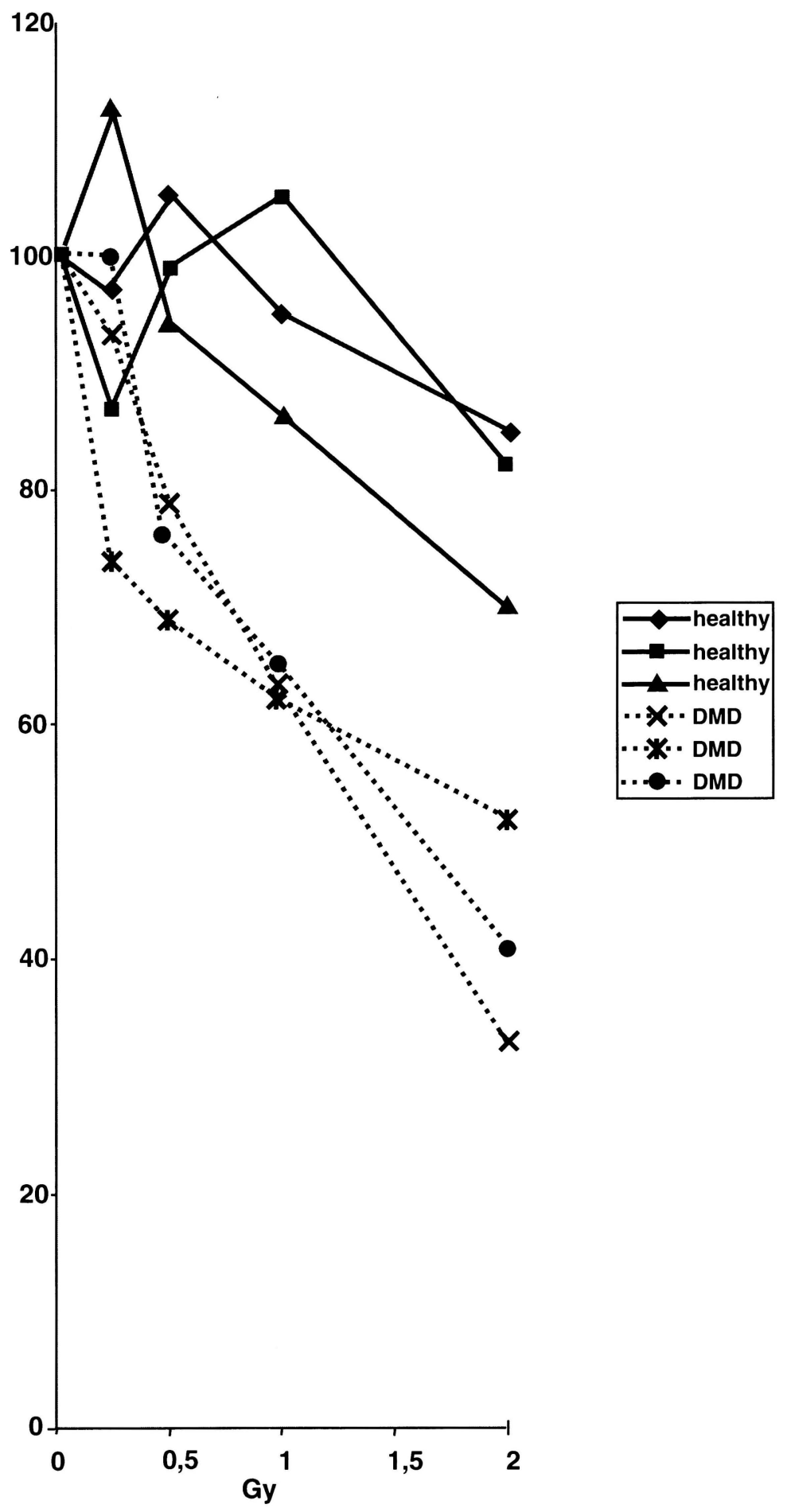

Figure 1. Results of pairwise comparison in three independent experiments. 


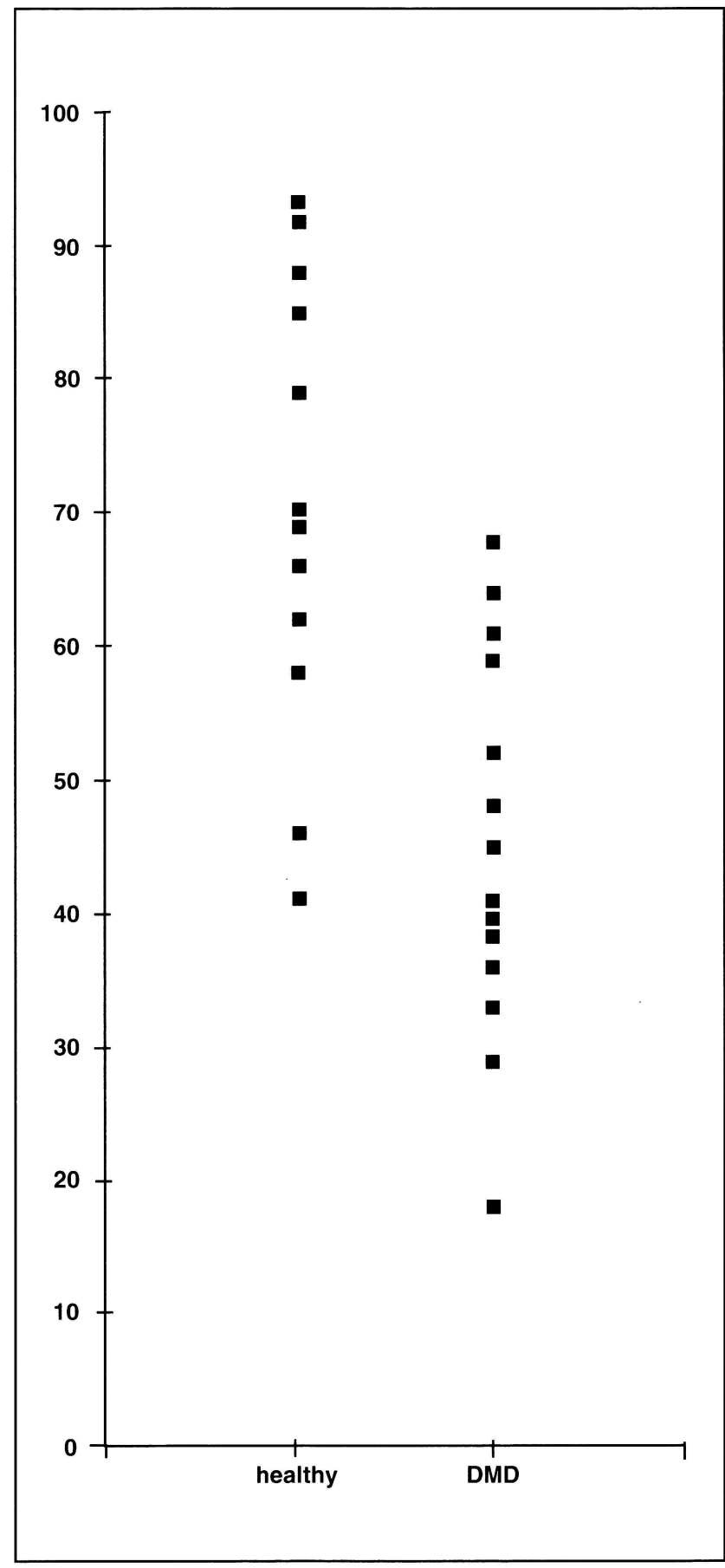

Residual proliferative activities

mean cpm 2 Gy

mean cpm 0 Gy

healthy $n=13$

$x=0.691 \pm 0.16$

DMD $\mathrm{n}=16$

$x=0.475 \pm 0.14$

Student t test

$$
\begin{aligned}
& t_{26}=3.6 \\
& p<.01
\end{aligned}
$$

Figure 2. The residual proliferative activities observed in 13 healthy LCLs and 16 DMD LCLs $48 \mathrm{~h}$ after 2 Gy irradiation. 


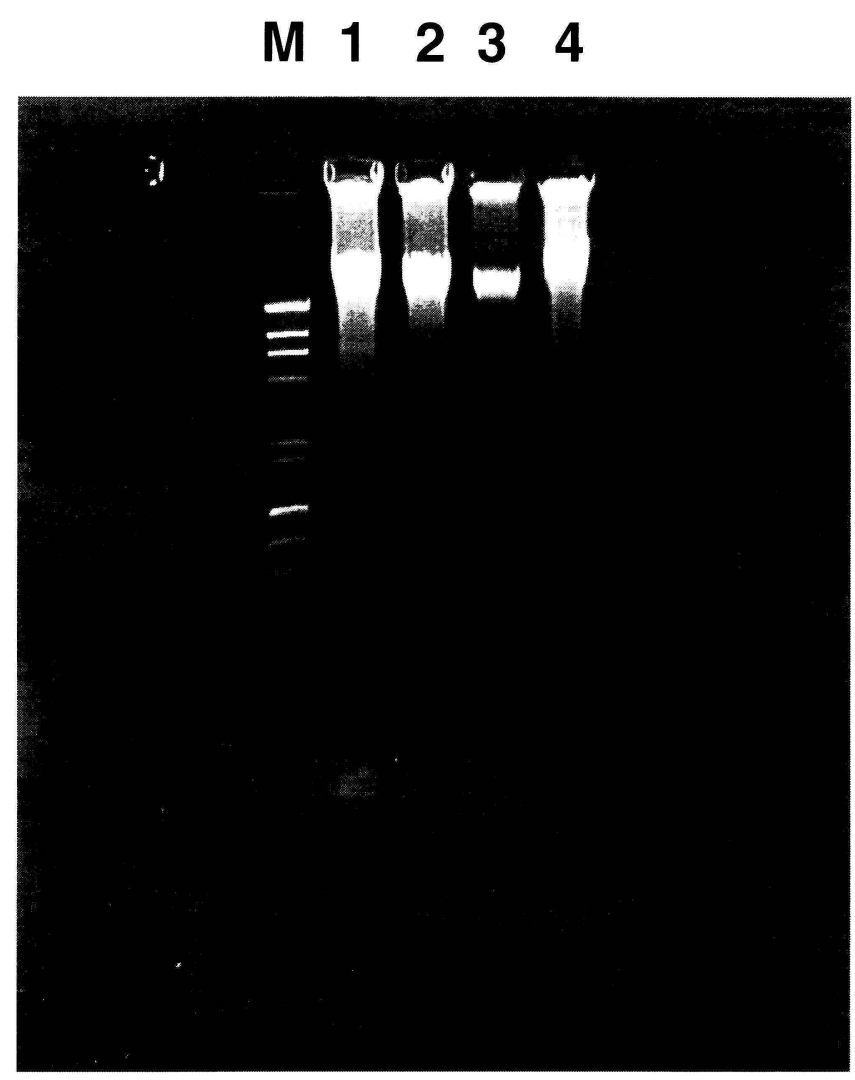

Figure 3. DNA fragmentation analysis. Lanes 1-2 healthy control - DMD

Lanes 3-4 healthy control - DMD irridiated 2 Gy

reported the identification of a novel product: a $71 \mathrm{kDa}$ protein (Dp71 or apodystrophin) encoded by a transcript generated by the distal part of the gene, corresponding to the cystein rich and carboxy terminal domain of the molecule (Lederfein et al., 1992).

The protein is widely distributed, but the relationship between Dp71 and disease and the function of the gene product has not been studied. Hugnot et al. (1992) however, by using a MoAb directed against the dystrophin carboxy terminal of the molecule portion were able to detect the transcript in LCLs from healthy subjects, but not in LCL from a patient with deletion of the dystrophin gene involving the C-terminal domain.

On the assumption that defect of the dystrophin isoform expressed in lymphoblastoid cells could be responsible for various membrane abnormalities we have compared $\mathrm{x}$ radiosensitivity in LCL from healthy subjects and DMD. The results obtained, showing an increased sensitivity in DMD cells, could confirm the hypothesis. Our results show that the low irradiation rates provided $(0.25-2.0 \mathrm{~Gy})$ were not able to cause any impairment of DNA synthesis within 24 hours in both healthy and DMD cell populations.

On the contrary, 48 hours post-irradiation DNA synthesis was impaired in irradiated DMD when compared to non-irradiated while no significant differences were still observed in cells from healthy subjects. 
Simultaneous evaluation of culture absolute cell number 48 hours after irradiation demonstrated a reduced number of cells in DMD irradiated cultures suggesting the $\mathrm{x}$-ray induction of cell lysis or an affect on the cell cycle length. Previous reports have shown that lymphoid cells are characterized by high radiosensitivity. While high doses are clearly responsible for cell necrosis, it has been recently recognized that also exposure of rat thymocyte to small doses (6Gy) of x-irradiation causes Ca++ elevation (Zhivotovsky et al., 1993). The Ca++ elevation results transitory but able to induce the irreversible DNA fragmentation characterizing apoptosis.

Similar observations in splenocyte population were not able to detect $\mathrm{Ca}++$ increase but confirmed DNA fragmentation $4 \mathrm{~h}$ post-irradiation. Because abnormal cytosolic $\mathrm{Ca}++$ increase has been reported as the major mechanism responsible for cell necrosis we have examined $\mathrm{Ca}++$ levels and the presence of DNA fragmentation in irradiated cells to investigate the possible occurrence of similar phenomena in determining the observed proliferative impairment. Post irradiation cytosolic $\mathrm{Ca}++$ evaluations, performed at 6, 24 and 48 hours were not able to detect any increase in $\mathrm{Ca}++$ level in both healthy and DMD irradiated cell populations, moreover no DNA cleavage in discrete fragments resembling apoptosis was detected in exposed lymphoblastoid cell lines.

These results suggested that cell lysis mechanism is not responsible for the impairment in the proliferative response observed in DMD LCLs, on the other hand a possible explanation to justify the reduced $3 \mathrm{H}$ uptake is related to the cell cycle length. In fact the experiments performed to confirm this hypothesis proved a diminished DNA synthesis in irradiated DMD cells after 24 hours cultures without differences in the absolute cell culture number, evidencing an increase sensitivity of DMD lymphoblastoid cells to small doses of $x$-ray that cause affection the cell cycle length.

It has been previously reported that DMD LCL cells are characterized by intrinsic cellular defect affecting membrane capacity, and the recent identification of a dystrophine isoform in such cell types could reasonably relate the absence of the protein in DMD cells to the abnormalities observed.

The weakness of the cytoskeletal compartment in DMD, in which the dystrophine related protein is normally involved in both mechanical tension and ion fluxes across cellular membrane, could explain the results obtained.

\section{ACKNOWLEDGEMENTS}

This research was supported by grants from the Ministry of Scientific Research (MURST 60\%) and Telethon - Italy.

\section{REFERENCES}

Ahn, A.H., Kunkel, L.M., (1993). The structural and functional diversity of dystrophin. Nat Genet., 3, 283-291.

Baricordi, O.R., Sensi, A., Balboni, A., Romeo, G., Rocchi, M., Melchiorri, L., Gandini, E. (1989). Impairment of capping in lymphoblastoid cell lines of Duchenne patients indicates an intrinsic cellular defect. Hum. Genet., 83, 217-219.

Di Virgilio, F., Fasolato, C., Steinberg, T.H. (1988). Inhibition of membrane transport system for organic anions block fura-2 excretion from PC12 and N2A cells. Biochem. J., 256, 959-963.

Franco, A.J., Lansman, J.B. (1990). Calcium entry through stretch activated ion channels in $\mathrm{mdx}$ myotubes. Nature, 344, 670-673. 
Fong, P.Y., Turner, P.R., Denetclaw, W.F., Steinhardt, R.A. (1990). Increased activity of calcium leak channels in myotubes of Duchenne human and mdx mouse origin. Science, 250, 673-676. Hugnot, J.P., Gilgenkrantz, H., Vincent, N., Chafey, P., Morris, G.E., Monaco, A.P., BerwaldNetter, Y., Koulakoff, A., Kaplan, J.K., Khan, A., Chelly,Y. (1992). Distal transcript of the dystrophin gene initiated from an alternative first exon and encoding a 75-KDa protein widely distributed in nonmuscle tissues. Proc. Natl. Acad. Sci. U.S.A., 89, 7506-7510.

Lederfein, L., Levy, Z., Augier, N., Mornet, D., Morris, G., Fuchs, O., Yaffe, D., Nudel, U. (1992). A 71-kilodalton protein is a major product of the Duchenne muscular dystrophy gene in brain and other nonmuscle tissues. Proc. Natl. Acad. Sci. U.S.A., 89, 5346-5350.

Mac Lennan, P., Edwards, R.H.T. (1990). Protein turnover is elevated in muscle of mdx mice in vivo. Biochem. J., 268, 795-797.

Menke, A., Jockusch, H. (1991). Decreased osmotic stability of dystrophin-less muscle cells from mdx mouse. Nature, 349, 69-71.

Murgia, M., Pizzo, P., Sandona', D., Zanovello, P., Rizzuto, R., Di Virgilio, F. (1992). Mitochondrial DNA is not fragmented during apoptosis. J. Biol. Chem., 267 n.16, 10939-10941.

Sensi, A., Venturoli, A., Traniello, S., Lucci, M., Vullo, C., Conighi, C., Mattiuz, P.L., Baricordi, O.R. (1984). Impaired HLA capping capacity of peripheral blood lymphocytes in Duchenne muscular dystrophy. J. Med. Genet., 21, 182-185.

Spencer, M.J., Tidball, J.C. (1992). Calpain concentration is elevated although net calciumdependent proteolysis is suppressed in dystrophin-deficient muscle. Exp. Cell. Res., 203, 107111.

Sudgen, B., Marks, W. (1977). Clonal transformation of adult human leukocytes by Epstein-Barr virus. J. Virol., 23, 503-508.

Turner, P.R., Westwood, T., Regew, C.M., Steinhardt, R.A. (1988). Increased protein degradation results from elevated free calcium levels found in muscle from mdx mice. Nature, 335, 735738.

Zhivotovsky, B., Nicotera, P., Bellomo, G., Hanson, K., Orrenius, S. (1993). Ca2+ and endonuclease activation in radiation induced lymphoid cell death. Exp. Cell. Res., 207, 163-170. 


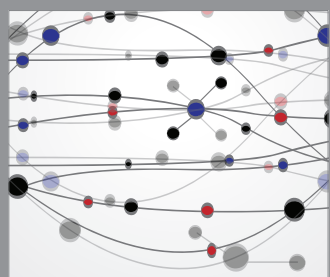

The Scientific World Journal
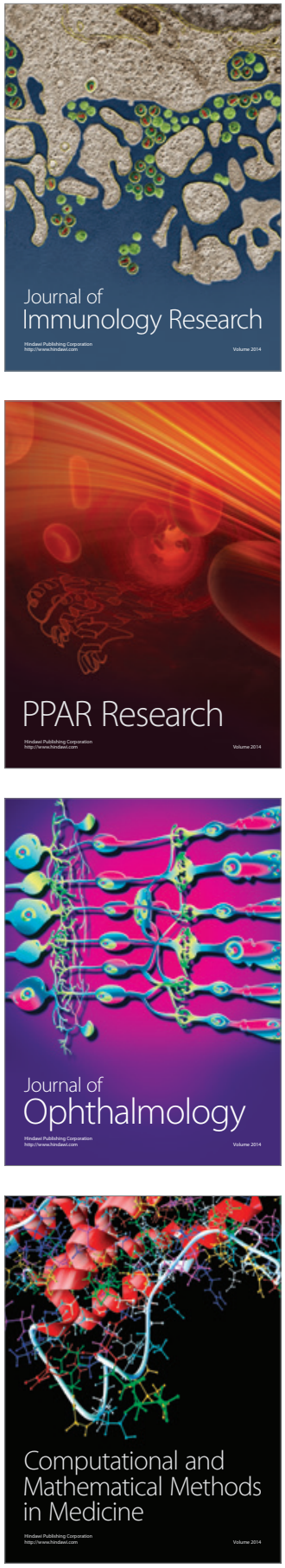

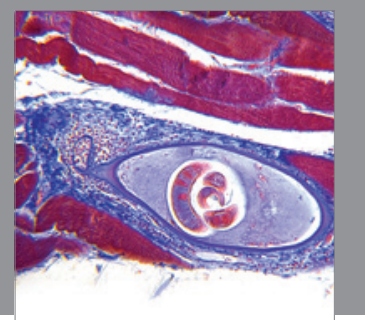

Gastroenterology

Research and Practice
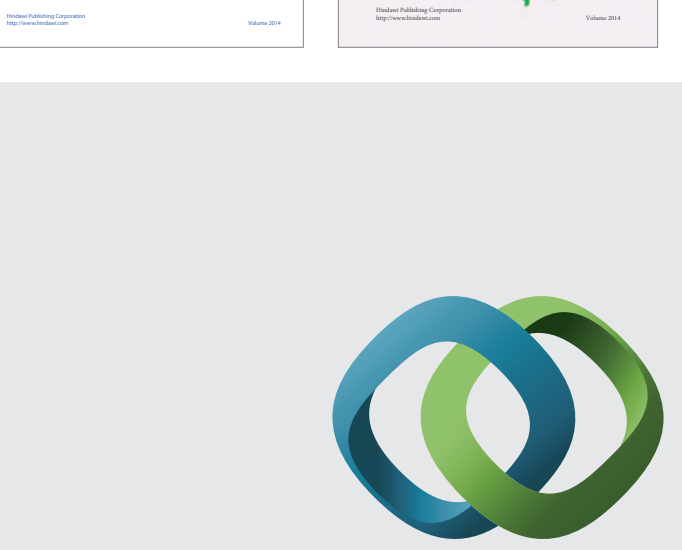

\section{Hindawi}

Submit your manuscripts at

http://www.hindawi.com
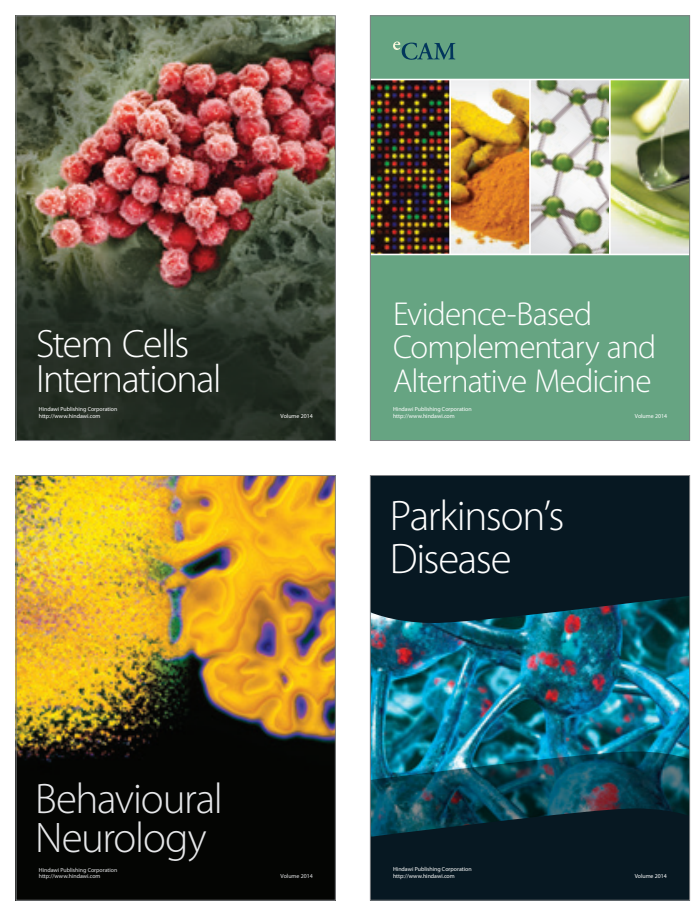

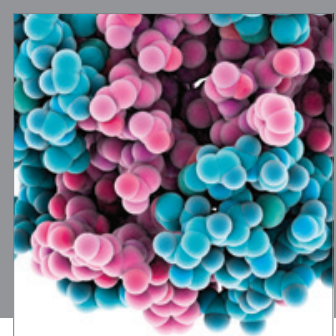

Journal of
Diabetes Research

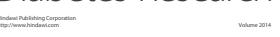

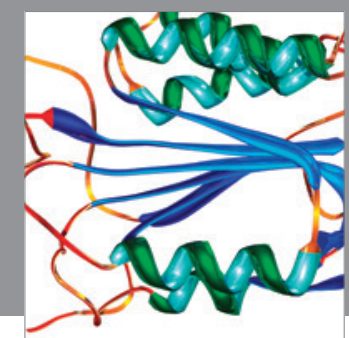

Disease Markers
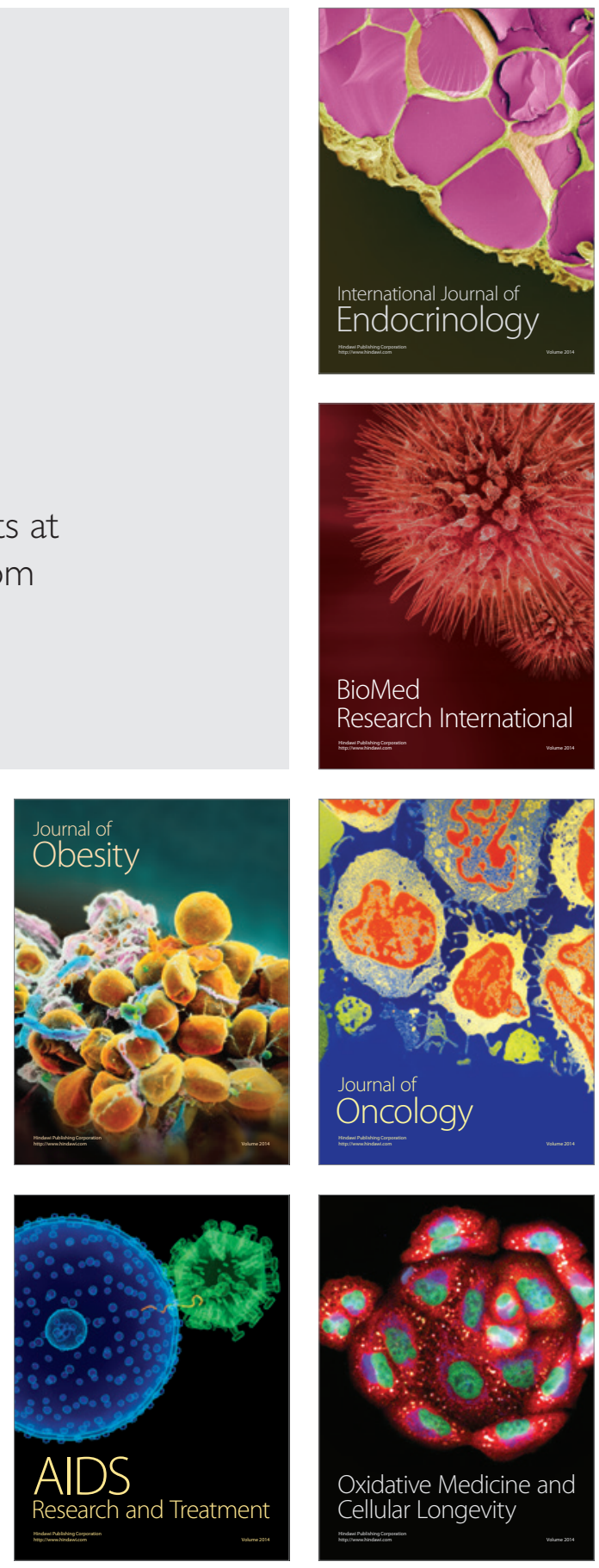